\title{
Improvement of Quality of Learning of Islamic Education at National Senior High School of Parepare
}

\author{
Sureda \\ Muhammadiyah University of Parepare \\ suredahamid31@gmail.com
}

\begin{abstract}
The quality of learning of Islamic education is a problem that is always a concern for the school educators. The learning quality of Islamic education is dynamic and complex so the detailed and in-depth study is needed. Islamic education as one of the core subjects in high school because it is the basic needs of learners as Muslims. A measure of successful learning of Islamic Education in school is when the learners are master and practice it. Islamic Education learning achievement is determined by the competence of educators as Islamic education executors in the classroom. Educators of Islamic education have a great responsibility to the quality of learning. Educators of Islamic education can comprehensively comprehend and implement learning effectively if done with a lesson study approach. Lesson study involves educators of Islamic education with peers identifying problems, finding solutions, instructional design, limited testing, evaluation, and verification, retesting, concluding, and socializing. A lesson study work procedures as an approach that can describe the learning problems and become a consideration in the design of quality learning.
\end{abstract}

Keywords: Islamic Education, Quality, Learning, Improvement

\section{INTRODUCTION}

An Islamic education in public schools is very important to be implemented, as a container for religious development of learners. Education is the need of every human being to be mature, both in the physical and spiritual aspects. Islamic education has challenges in public schools because learners are more likely to learn in general lessons than in religious studies. In another aspect, the psychological upheaval of learners at the age of high school becomes a challenge for teachers to present the lesson. Great expectation of quality improvement and teacher competence continues to be realized as an effort of realization of national education aspiration [1]. National education maximizes the potential increase of learners in the form of faith and piety, akhlakul karimah, healthy physical and spiritual, intelligent and creative, and become a democratic and responsible citizen[2], [3].

An educational activity at the level of the educational unit is a process toward the goal to be achieved, through the process of individualization or personalization, socialization of enculturation, professionalization, civilization, habitualization, and humanization. The educational process occur the interaction between educators and learners. Educator's job builds human potential, creative potential, the potential of religiosity, and another potential, so that learners can develop positively [4], [5]. The growing potential of learners has implications for independence, optimism, and innovation in building civilization. The strengthening of Islamic education through learning should be a high focus of attention for the stakeholders [6]. The learning of Islamic education, both in the classroom and outside the classroom, is the key to the success of education in schools [7], [8].

The learning is an activity that involves all the learning resources within the learner's environment, to get to its death [9]. Learning interaction takes place consciously and deliberately, as well as motivates learners that include themselves learners, family, school, and culture. In urgent learning to manage by taking into account the principles of learning interaction that is preparing materials and learning resources, choose methods, tools, and teaching aids, choose the approach, and conduct an evaluation after the end of learning then more simply every learning involves several components, such as goals, materials, methods, media, and evaluation[10].

\section{METHOD}

This type of research is field research (field research) that is qualitative. This method is relevant for theory development through data analysis from the field (empirical). The approach is a case study on Islamic education at National Senior High School of Parepare City. The paradigm of this research is pedagogic, theological, and psychological.The data source is primary and secondary. Primary data sources are consist of principals, supervisors, and educators of Islamic education, and secondary data sources consist of quality teaching documents and competency examination documents, both in schools and in the Department of Education and the Ministry of Religious Affairs. The researcher used observation, interview, document study and data from trial result and activity product. The data analysis techniques are 1) word reduction; 2) data presentation; and 3) drawing conclusions/verification. 


\section{RESULT}

The development of competence of Islamic education educators at National Senior High School of Parepare City has not been received high attention from local government through Education Office of South Sulawesi Province. The Provincial Education Office with relatively slow access and coordination (compared to the Municipal Education Office), has implications for the attention and improvement of the competence of Islamic education educators. Support for improving the competence of educators of Islamic Religious Education can be through the granting of further study permits, engaging in education and training activities, encouraging professional organizations such as Teacher Education Republic of Indonesia, Teacher Academy of Islamic Education and Indonesian Teachers Association to be active in fostering teacher competence, means of learning to schools, and so on.

The facts found that there has been no development of Islamic education educator competence through lesson study approach. The development of Islamic education educator competence through the lesson study program is considered very important to comprehensively comprehend the duties and responsibilities of Islamic education educators to their profession. Educators gain awareness, knowledge, perspective, and skills in performing their duties if trained through the application of lesson study. Lesson study presents the participation of Islamic education educators so that learning can run effectively and efficiently in achieving goals.

An Islamic education educator at National Senior High School in Parepare City started with brainstorming on the problems faced in classroom learning. Including curriculum 2013 that must be adapted to the situation and conditions in each school. Islamic education educators provide their respective views on the problems experienced in implementing learning in the classroom. Islamic education educators analyze issues both macro and micro and based on learning components, such as objectives, materials, teachers, learners, media, methods, evaluation, and learning environment.

The result of brainstorming of Islamic education teachers at National Senior High School in Parepare was concluded that learners do not have interest in learning of Islamic education. (as other lessons), curriculum policies are often changing, learning objectives that are less relevant to the condition of learners, saturation learners because students the non-biased material (novelty and proximity aspects), the limitations of learning media in schools, the ability to choose the learning method, the complexity of the assessment of learners, and the synergy of the school is not optimal.

Various learning problems submitted by educators of Mapel of Islamic education at National Senior High School in Parepare City are as follows:

1) The latest 2013 curriculum that is too high learning achievement making it difficult for learners to achieve it;

2) The design of the lessons of Islamic education is impure from the results of classroom studies;
3) The number of students who are not yet fluent in writing the Qur'an, reciting the prayer, and other obligations in the teachings of Islam;

4) The development of teaching materials has not fulfilled novelty, proximity, humor, and conflict aspects;

5) Limited media and learning resources available in schools;

6) Selection of strategies and methods of learning are still limited;

7) Complex and complex evaluation system;

8) The synergy of the school has not been well established;

9) Less conducive classroom environment in learning. After brainstorming, the Islamic education is collected back together to find a solution based on the ability and condition of the school. The various solutions offered by each participant are accompanied by basic, experience, an example so that it is richer in the lesson study. Alternative solutions provided by teachers are collected and shared among other participants, often devoted to determining the most appropriate solution among the right and the more solutions the better for the learning perspective that is designed in the future. Probably, the proposed solution is irrelevant to a particular school, but at other schools, it is more relevant. In the problem-solving aspect is very interesting attention from educators of Islamic education participant's lesson study.

The teacher of Islamic educations provides views, ranging from simple aspects, realistic, to complex and abstract aspects. The existence of solidarity in the lesson study forum becomes an attraction for the teacher of Islamic education complement each other and improve their knowledge, insight, and improvement of teaching competence. Description of the condition of this activity runs effectively, relaxed atmosphere, and filled by inputs academically and theoretically by companion lesson study.

The solutions as conclusions provided by the teacher of Islamic education are as follows:

1) Mapping of learning objectives with more real and detailed indicators and tailored to the conditions of learners: Teachers of Islamic education are important in designing classroom-based learning, assessing the condition of learners, classroom facilities, and other relevant conditions;

2) Learners need intensive and massive assistance in the mastery of literature reading the Qur'an, memorize the reading of prayer, diligent prayer in congregation, with akhlakul karimah, and various other religious obligations;

3) Teachers of Islamic education are important in developing teaching materials by considering aspects of novelty and the dynamics of science, connecting with social conditions within the learner, illustrating in a humorous and challenging atmosphere;

4) Teachers of Islamic education are more creative in designing media and learning resources to suit their learning needs; 
5) Teachers prepare evaluation tools to find out the developmental stages of learners such as recorders; teachers often partner with honorary teachers to provide student assessments; teachers work with parents to get additional data related to learners' profiles;

6) Establish support from principals, educators, staff, and stakeholders for the success of Islamic education learning in the classroom;

7) Organizing a conducive classroom; arranging tables with dynamic shapes; provide good air ventilation and light.

In the next stage, educators of Islamic education as lesson study participants gathered to discuss and discuss lesson planning. Learning that is designed refers to an agreed solution to the learning problem. This stage is implemented learning design by adapting the result of problem-solving which becomes conclusion in lesson study forum. Educators of Islamic education discuss every syllabi component and lesson plan. Once completed, the educators of Islamic education sets who will practice as a limited trial and becomes an observer in the learning exercise.

The results of the experimental design of learning in the forum limited, the observer provides a record of corrections to the weaknesses of learning. Further, may discuss again by the participants of lesson study and its recommendations into consideration in revising the design of learning. The learning design results are retested, and the observer states that they are good and meet the standard of learning. The conclusion of lesson study activities, educators of Islamic education socialize the Islamic educators to be a consideration in designing of Islamic education learning at National Senior High School in Parepare City.

\section{CONCLUSION}

The achievement of Islamic educational competence at National Senior High School in Parepare City through Lesson Study approach is very important and urgent which have done by the educators. The stages of the implementation of lesson study activities are identification of problems experienced by the educators of Islamic education in learning, problem-solving and alternative solutions, learning planning that refers to the solution of learning problems, the implementation of learning as a test conducted by educators and other educators become observers, then evaluated and verified again for a second try. Then the final evaluation result is concluded and disseminated to other Islamic educators. Lesson study activity is very significant and massive for increasing the competence of educators of Islamic education at National Senior High School in Parepare City.

\section{REFERENCES}

[1] D. Al Hamdani, "THE CHARACTER EDUCATION IN ISLAMIC EDUCATION VIEWPOINT," J. Pendidik. Islam, 2016.

[2] M. R. M. Nor and M. Malim, "Revisiting islamic education: The case of Indonesia," J. Multicult. Educ., 2014.

[3] M. Nakamura and S. Nishino, "Islamic Higher Education in Indonesia," High. Educ. Policy, 1993.

[4] R. Rusdianto, "INTERAKSI NEUROSAINS HOLISTIK DALAM PERSPEKTIF PENDIDIKAN DAN MASYARAKAT ISLAM," HUNAFA: Jurnal Studia Islamika. 2015.

[5] N. Rifai, The emergence of elite Islamic schools in contemporary Indonesia: A case study of Al Azhar Islamic School. 2006.

[6] S. Suyatno, "Integrated Islamic Primary School In The Middle-Class Muslims Indonesia Conception," Analisa, 2015.

[7] R. A. Lukens-Bull, Islamic higher education in Indonesia: Continuity and conflict. 2013.

[8] C. N. Hashim and H. Langgulung, "Islamic Religious Curriculum in Muslim Countries: The Experiences of Indonesia and Malaysia," Bull. Educ. Res., 2008.

[9] A. Husin, "Education for Islamic pluralism: Lessons from Indonesia," Islam Civilisational Renew., 2009.

[10] D. Afrianty, "Islamic education and youth extremism in Indonesia," J. Policing, Intell. Count. Terror., 2012. 